\title{
1.はじめに
}

生体系に類似した情報処理機構と高度な並列処理能力を持つ, 人工的な神経回路糊によ る新しいタイプの知的情報処理用コンピュータに対する期待は極めて大きい.しかし，そ の実現までにはまだ多くの挑戦すべき問題が残されている。中でも，(1)多数の神経細胞間 のシナブシス結合とその加重の積和演算をどのように実現するかというハードウエアの問 題と, (2)そのような人工的な神経回路網に対してどのようなブログラムまたは学習をさせ れば目的とする情報処理を高度な並列性をむって実行することがでるかというソフトウ エアの問題を解決することが不可欠である.ここでは，(1)の問題に関して光技術の持つ可 能性について論じるとともに, 光技術を用いた神経回路網のハードウエア化の研究の現状 を紹介する。

\section{2. 光技街の持つ可能性}

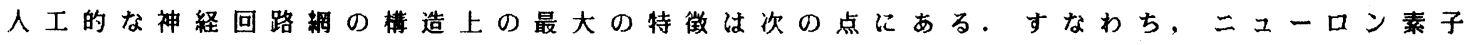
は非線形な阈值処理をするだけのごく単純な機能しか持たないかわりにその数が極めて 多く, しか屯, それらが相互に非常に密て複雑に結線されている。そして, この結線の相 互結合の度合をあらわすシナプシス荷重には, 学習過程を通じて, 神経回路網がコンピュ 一タとして働くためのプログラムやデータが書き込まれる.非線形動作をする多数の二ュ 一ロン素子がこの荷重付き結線を介して相互作用しながら状態を変える非線形力学過程を 通じて目的とする計算が実行される.したがって,この結線はこューロコンヒューティン グの最む重要な部分となる. 光技術はこのような特徽を持つ神経回路網のハードウエア化 に必要な以下の 3 つの基本的な機を実現する可能性を持っている.

(1)ニューロン素子間のグローバルで密なインターコネクション

(光インターコネクション)

(2)シナプシス加重の超並列アナログ積和演算棈

(マトリックス・ベクトル樌の並列光アナログ演算器 )

(3) ニューロン素子の阈值関数型の非線形增幅機 棒

(非線形位相共役結晶)

\section{1 光インターコネクショ.ン1.2)}

まず，情報の伝達媒体としての光子は電子に較べて信号相互の無誘導性・非千涉性とい った優れた性質がある。そのため, 例えば, 3 次元空間内で多数の光ビ一ムを多重に交差 させることによる神経回路網の 3 次元高密度結線の可能性が生じる. また 光結線は光ビ 一ムを広げて照射することによるグローバルな放送型の結線など神経回路網の必要とする 結線を実現しやすいという長所を持つ。さらに，光結線は，光ビームチャンネルの空間的 分解能の高さに加えて, 時間信号の伝般の高速性と周波数の広带域性という大きな特長を 借えている.

\section{2 超並列光アナログ樌和演算 ${ }^{31}$}

次に，光が物体を透過したり物体から反射される際には，その透過光または反射光の強 
度は入射光強度に物体の透過率または反射率をかけたものになる。この積の演算は空間的 広吕りを持つ物体表面の各場所場所て同時に並列かつ独立に行われる。さらに, これらの 各場所からの光をレンズなどの光学素子ょり一点に集光することにより光強度和として和 の演算を実現することができる。したがって, 各ニューロンの興套状態を空間的な光強度 分布で表現し，各シナブシス加重を空間的な透過（反射）率分布で表現する空間光変調器 に人射させ，その出力光を集光して検出することによりシナプシス加重の超並列アナログ 樌和演算を䊩时に行うことができる。

\section{3 值形韭線形光增幅}

ニューロン素子の成值形の非線形增幅は, 本来, 光よりはむしろ電子技術の方がはるか に実現し易い能であるが, B S O や B a T i O 3 などの非線形光学結晶を用いた最近の 位相共役波発生技術により，光の波動場に対して直接非線形增幅作用をする機構加実現て きるようになってきた。

\section{3.光技街を用いた神経回路调のハードウェア化}

神経回路䉽の実莣に光技術を用いる方法としては, インターコネクションのみに光を用 いて残りの機粠をすべて電子技術で実現する, 電子技術主体の光・電子ハイブリッド式か ら, 前述の 3 つの棈の全てを光で実現するオール光式のものまで, 種々のレベルのむの が考えられる。また, 前者の場合, 八ードウェア棰成のどの階属で光インターコネクショ ンを用いるかによってさらに幾つかの異なる形態が考えられる。

\section{1 仮想神経回路羘エミュレートフロセッサモジュールの光結線}

T R W の M a r k IV 4) のような, 現存のディジタルコンビュータ技術を基硌にした方法 は, シリコン素子のスイッチング速度が生体ニューロンのスイッチング速度に較べてはる か比高速であることを利用して，個々の高速なシリコン素子を時分割的に用いることによ

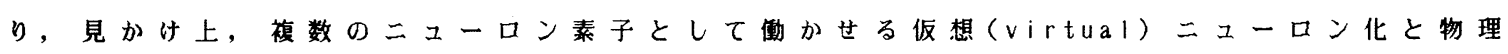
的線路を時分割的にマルチプレックスして利用する 仮想結線化の思想に基ついている。この方式は種々 の神経回路赫を自由にフログラムできる代偵として 計算速度加遅い。ママルチプロセッサの数を增して並 列度を上げて高速化しょうとすると，プロセッサモ ジュール間のバスの通信容量が問題となる。図1は, 仮想ニューロンエミュレータのブロセッサモジュー ル間の放送型の並列バス接続を，ホログラムを用い た自由空間の光結線により高速広带域化をはかり, 結線の通信容量を高め, 仮想二ューロンのスイッチ

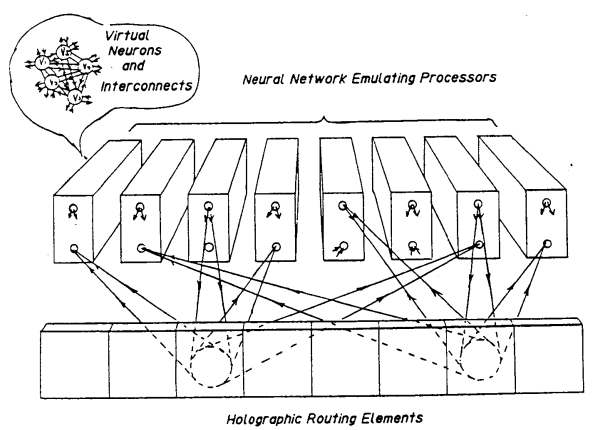

図1.モジュール間の光結線 ング速度を上げようとする考えの1例を示したものである。このような放送型光バスは, 仮想神経回路椆モジュールの光結線にはまだ実際に使われていないが, 電総研のマルチプ ロセッサDialog.Hのようなディジタルコンピュータでは既に実駼が進めらており5, 比較 的近い将来汇実用化が期待し得るものと考えられる.

3. 2 VLSI I ニーロンチッフの光結線

$\mathrm{N}$ 個のニューロンの全てが相互に接続された最も一般的なシナブシス結合の組合せを可 能にするには, N ${ }^{2}$ 個の結線が必要である. [ 仮想ニューロン]+[仮想結線]方式の低 速性を基本的に解決するには, ニューロン素子と結線を物理的(physical)に実現する必要 
がある.その場合、シリコン表面積の大部分はシナブシス結線のための抵抗マトリックス で占められることになるので, 集積可能なニューロンの数は結線によって制限される。奴 |1研で開発中のチップのニューロン数はまだ $N=256$ はある6り.このように，1つのチップ に载るニューロンの数 $\mathrm{N} に$ 制約があるので、大規模な神経回路網を構成するには, $\mathrm{m}$ 個の チップを用いてニューロンの総数を $\mathrm{mN}$ 個に拡張して行くことになろう.全てのこュ一ロン が相互に接続された最も一般的なシナブシス結合の組合せを可能にすることを考えると， $m(m-1) N^{2}$ 個の結線は外部ピンを通してチッフ間で行わなければならない.これに必要な外 部ピンの数 $\mathrm{P}$ は, $\mathrm{P} \sim \mathrm{N}$ となり, 通常のディジタルロジック $\mathrm{L} S \mathrm{I}$ のトランジスタ数 $\mathrm{N}$

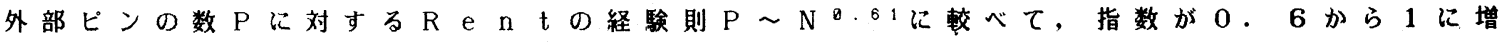
加している. こューロンチップの場合, チップ内結線にシリコン表面䄼の大部分を消費す るため現在のところ $\mathrm{N} の$ 值はまだ小さいが, 将来大規模な集積化に成功した場合にはチッ プ間の結線が問題となるであろう.

図 2 は, ニューロンのVLS I チップ間の結線を, 反 射型ホログラムによる自由空間結線, または光導波路を 用いた光結線で実現することを考えた概念図である。こ の場合は, 外部ピンに代わるものとして, 受発光素子の アレーを用いるので, シリコンのニューロンと G a A s の発光素子を一体化したＯE I C チップの開発が必要に なろう. 光結線の高速広带域性を生かして信号を高度に マルチプレックスすることにより，受発光素子数を減ら すこともできよう.（以上に述べた 2 つの例は, 筆者自

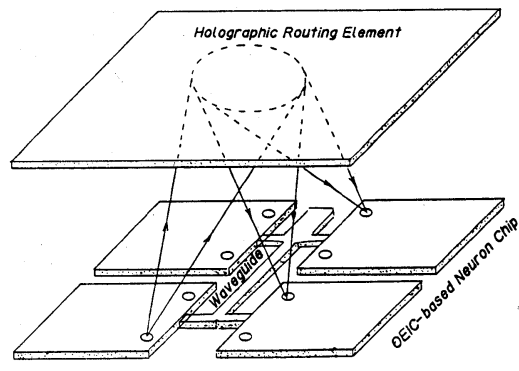

図 2.チップ間の光結線

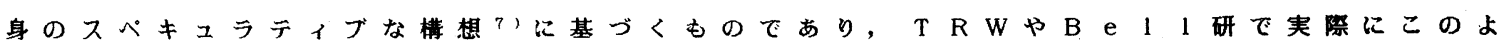
うな実験をしているわけではない。)

\section{3 電子ニューロン素子の光結線}

図4 は, $\mathrm{Ca} \mid \mathrm{tech}^{8}$ で試作されたホップフィールドモデに基つくく連想メモリの概念図 である.ニューロン素子間の結線とシナプシス加重のアナログ積和演算を光で行い, こュ

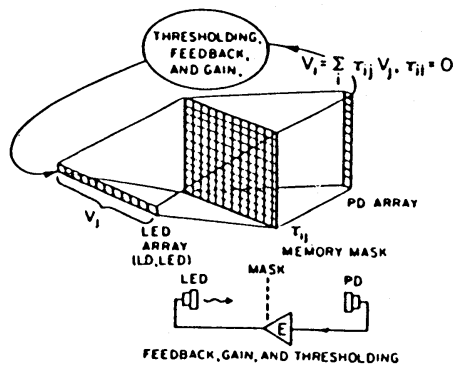

(a)

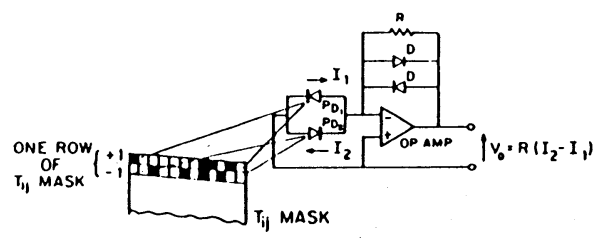

(b)

図 4. 光連想メモり (Farhat,Psaltis et.a. ${ }^{91}$ )
一ロン素子の閥值関数型の非線形増幅を電子的に行っ たむのである.全系は, 前述の並列光アナログ穔和演 算器に國值処理の非線形フィードバック機を楱をた ものからなり，横に配列した発光ダイオードアレーが 神経細胞の興夽状態に対応して明減する。中央のマス クには連想記境のための相関行列が光強度透過率とし て記録されていて, 結線のシナプシス荷重をかける役 割をする。綐に配列したフォトダイオードアレーは， シナプシス荷重付きで他の神経細胞からの出力を受け, それを電気信号として非線形フィードバック变換して 神経細胞の次の状態を新たに決定する。各ニューロン に適当な初期值を与えフィードバックを綝り返すこと により, 初期値から連想される記境の状態に収束して いく. マスクの透過率は正值のみなので, 負の結合を 表す部分からの透過光はフォトダイオードの光電流の 向きが逆になるようにして差動検出をする。 


\section{3 ホログラフィック光連想メモリ}

Caltech ${ }^{9}$ ) やHughes研究所 10)の, ホログラムと 位相共役鏡（ $\mathrm{P} C \mathrm{C}$ ) 用いた光連想メモリは結線 とシナプシス加重の積和演算とニューロンの非線形 增幅機構の 3 者をすべて光技術で㯨成した神経回路 糊である.図4 この場合, ニューロンは離散的に独立した素子とし て存在するのではなく, P C M を形成する B a T i $0_{3}$ の結晶内部に空間的に連続に分布しており, い わば, ニューロン場というべき状態を形成する。す なわち, 盛值を越えた光強度を持つ部分だけが增幅 作用を持ち P C M 波を発生するという非線形作用を 利用したものである。このような方式は, プログラ マビリティーはあまり高いとはいえないが, 画像の ような空間情報に対しては, 光の持つ特徽を非常に よく生かした方式といえよう. B a T i $0_{3}$ の結晶 の応答速度は, 系を光が伝搬する時間に慗べて遙か に遅いので,この場合は，いわば完全にスイッチン グ速度リミテッドの状態にある。低エネルギーで高 速に応答する結晶を必要とする状況は, ティジ夕ル ロジックデバイスに対する要求にあい通じるところ がある。

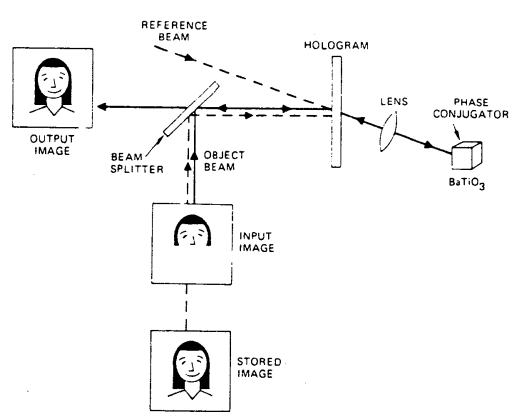

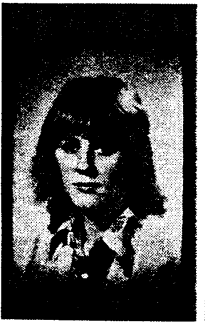

(a) IMAGE STORED
IN MEMORY

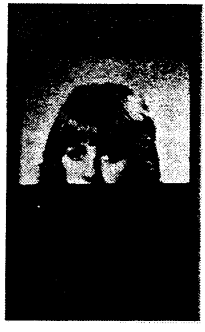

(b) INCOMPLETE
INPUT IMAGE

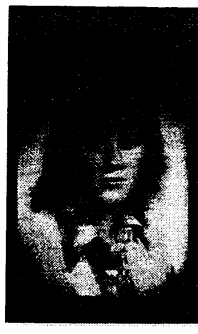

(c) ASSOCIATED
OUTPUT IMAGE

図 4.木口ク”ラフィッ光連想メもリ ( Y.0wechko et. a ${ }^{10)}$ )

\section{5. まとめ}

人工的な神経回路網を棈成する上での電気結線の持つ問題点を論じ, それに代わるもの として光結線を用いる提案を紹介し, その棈想を述べた。光結線は前述のような利点を持 つ一方, 学習能を与えるために必要なシナブシス荷重変化を結線上でダイナミックに実 現するにはどするかという基本的な問題を抱えている。また，光結線に用いるには単に 解像力だけてはなく, エネルギー, アライメント, 集積技術との整合性, など末解決の問 題をクリヤーする必要があろう.

\section{参文文献}

1) J.W.Goodman et. a 1: Proc. IEEE 72 (1984) 850 .

2)武田光夫：応用物理 56 (1987) 361 . 3) J.W.Goodman et. a 1: 0pt. Lett. 2 (1978) 1 .

4)R. Hecht-Nielsen: Próc. SPIE, Vol. $634(1987) 277$.

5 ) 鈴木基史（他）: 電子情報通信学会技 術研究報告 0 Q E 85-175（1985） 31 . 6 )"Neural Networks for Computing,"
AlP Conference Proceeding 151, j.S.Decker ed., American Institute of Physics $(1986)$.

7)武田光夫：光学 16 (1987) 366.9.

8) N.H.Farhat, D.Psaltis, A.Prata, and

E.Paek: Appl. Opt. 24(1985) 14614.

9) A. Yariv, S-K. Kwong, and K. Kyuma

Appl. Phys. Lett. 48, (1986) 11

10) Y. 0 wechko et. a 1: Proc. SPIE

vol.700 (1986) 296 . 